УдК 336.1: [338.43: 634]

DOI https://doi.org/10.32851/2708-0366/2021.6.5

Галат Л.М.

кандидат економічних наук, доцент,

Херсонський державний аграрно-економічний університет

ORCID: https://orcid.org/0000-0003-0075-9730

Galat Larysa

Kherson State Agrarian and Economic University

\title{
ДЕРЖАВНА ФІНАНСОВА ПІДТРИМКА ГАЛУЗІ САДІВНИЦТВА ЯК ФАКТОР ПІДВИЩЕННЯ ІІІ КОНКУРЕНТОСПРОМОЖНОСТІ
}

\section{STATE FINANCIAL SUPPORT OF THE HORTICULTURE INDUSTRY AS A FACTOR OF INCREASING ITS COMPETITIVENESS}

У статті розглянуто передумови, сучасний стан, тендениії розвитку та формування конкурентоспроможності галузі садівництва в Украӥні і вплив на иі процеси державної фінансової підтримки. Установлено, щзо виробництво плодів і ягід в Україні зростає переважно за рахунок закладання нових садів, створення належної сучасної інфраструктури галузі, шзо здійснюється здебільшого завдяки державній фінансовій підтримиі через механізми компенсаиії витрат як на відновлення садів, так і на створення інфраструктури для догляду, переробки, реалізації продукиії. Визначено деякі иляхи вдосконалення механізмів державної підтримки галузі садівництва та суміжних виробничтв і сервісів. Державна підтримка має бути спрямована на подолання "слабких місиь» у галузі, на переважну увагу тим виробникам, які є генераторами інновачійного розвитку та зростання галузі. Способом державної підтримки слід уважати і діяльність органів місчевого самоврядування, спрямовану на підтримку кооперачії малих товаровиробників, які вирощують, збирають переробляють та реалізують плодово-ягідну продукиію.

Ключові слова: садівниитво, індустріальне садівництво, виробництво, урожайність, споживання фруктів та ягід, державна фінансова підтримка, державна програма, конкурентоспроможність галузі, інфраструктура галузі садівництва.

В статье рассмотрены предпосылки, современное состояние, тендениии развития и формирования конкурентоспособности отрасли садоводства в Украине и влияние на эти проиессы государственной финансовой поддержки. Определено, что производство плодов и ягод в Украине растет в основном за счет закладки новых садов, создания надлежащей современной инфраструктуры отрасли. Определены некоторые пути совершенствования механизмов государственной поддержки отрасли садоводства и смежньх производств и сервисов. Государственная поддержка должна быть направлена на преодоление «слабых мест» в отрасли, на преимущественное внимание тем производителям, которые являются генераторами инновационного развития и роста отрасли. К методам государственной поддержки следует отнести и деятельность органов местного самоуправления, направленную на поддержку кооперации мальх товаропроизводителей, которые выращцвают, собирают, перерабатьвают и реализуют плодово-ягодную продукцию.

Ключевые слова: садоводство, индустриальное садоводство, производство, урожайность, потребление фруктов и ягод, государственная финансовая поддержка, государственная программа, конкурентоспособность отрасли, инфраструктура отрасли садоводства.

The article considers the preconditions, current state, trends in the development and competitiveness of the horticultural industry in Ukraine and the impact on these processes of state financial support.

It is noted that in the process of market reforms the volume of horticultural production decreased by more than 5 times, the industry was in decline, consumer demand for fruits and berries of domestic origin was not met. It is established that the building potential of the horticultural industry is due to the growing demand for berries and fruits in the domestic market, 
investment attractiveness of the industry due to rising prices for horticultural products in Ukraine and the world, the implementation of state financial support programs.

It is established that the production of fruits and berries in Ukraine is growing mainly due to the establishment of new gardens, the creation of proper modern infrastructure of the industry, which is carried out mainly through state financial support through mechanisms to compensate for the restoration of gardens and infrastructure for care, processing, sale products.

It is established that due to the state support of the industry it was possible to stabilize its condition and increase the potential for further development, however, the volume of fruit and berry production in 1990 has not yet been reached.

The geography, functional purpose and practice of providing state financial support to horticultural enterprises are considered.

It is established that despite the wide range of areas of state support for horticultural enterprises, financial support can be expected mainly by large enterprises, institutional problems arise for small farmers and private farms.

Some ways to improve the mechanisms of state support for horticulture and related industries and services have been identified. State support should be aimed at overcoming "weaknesses" in the industry, with priority given to those producers who are generators of innovative development and growth of the industry. The activity of local self-government bodies aimed at supporting the cooperation of small producers who grow, collect, process and sell fruit and berry products should also be considered a way of state support.

Key words: horticulture, industrial horticulture, production, yield, consumption of fruits and berries, state financial support, state program, competitiveness of the horticultural industry, infrastructure of the horticultural industry.

Постановка проблеми. Важливими основними показниками конкурентоспроможності галузі садівництва України є як розширення ії експортного потенціалу, так і зростання рівня та динаміки розвитку внутрішнього ринку плодів і ягід, підвищення забезпеченості населення країни плодово-ягідною продукцією належної якості. За період так званої «перебудови» та перші роки трансформації української економіки ( 1985 по 1999 р.) обсяги виробництва продукції садівництва скоротилися більше ніж у п’ять разів. Окрім того, занепад галузі у 90-ті роки підкреслювали експансія імпорту фруктів, навіть тих, які в природно-кліматичних умовах України мають бути більш продуктивними, ніж в інших країнах, технологічна відсталість, відсутність належної інфраструктури (сховища, переробка), без яких галузь садівництва не може розвиватися.

Незважаючи на щорічні коливання в обсягах валового виробництва плодів та ягід, в останні роки спостерігається позитивний тренд зростання виробництва продукції та розвитку галузі. Нарощування потенціалу галузі садівництва відбувається під дією кількох основних чинників, серед яких: стійкий попит на ягоди і фрукти на внутрішньому ринку протягом року на тлі незадоволеності потреб внутрішнього сповивача продукцією вітчизняного виробництва; збільшення кількості людей, що надають переваги здоровому харчуванню та збільшують власний попит на фрукти та ягоди; через зростання цін та попиту на продукцію садівництва як в Україні так і світі продукція садівництва стає більш привабливою для виробництва для вітчизняних товаровиробників і для нових інвесторів; програми державної фінансової підтримки галузі, що діють близько 20 років.

Сучасний глобальний ринок плодово-ягідної продукції стає більш конкурентним, сегментованим, вимогливим до якості та безпеки плодів, потребує нових видів продукції, сортів та видів рослин. Вагомим чинником, що визначає тенденції та перспективи розвитку галузі садівництва, $є$ її розвиток у кооперації із суміжними галузями та видами діяльності: переробкою, доробкою, пакуванням, зберіганням, сертифікацією, матеріально-технічним забезпеченням та ін. Галузь садівництва достатньо капіталоємна, віддача від коштів, інвестованих у сад, віддалена в часі на роки. За існуючих у поточний період ставок кредитних ресурсів та умов їх отримання для сільгоспвиробників подальше нарощування потенціалу галузі садівництва без участі держави неможливе. 
Аналіз останніх досліджень і публікацій. Значну увагу дослідженню економічних аспектів розвитку галузі садівництва, іï фінансового забезпечення, сучасним тенденціям на українському ринку плодоовочевої продукції присвячено роботи низки вітчизняних науковців: І.А. Сало, О.М. Шестопаля, В.В. Писаренка, Б.В. Духницького, Ю.В. Кернасюк, Г.С. Савенко, Н.А. Карасьової, І.В. Гончарук, Г.В. Шевчук, Л.П. Слепцової, Л.О. Барабаш, К.В. Мазур та ін.

Висвітленню проблем конкурентоспроможності галузей аграрного сектору приділяли увагу В.Г. Грановська, О.М. Бородіна, І.В. Прокопа, Н.І. Патика, О.В. Ходаківська, Ю.А. Авраменко та ін.

Дослідженням стану розвитку галузі садівництва, участю держави у ії відродженні опікуються фахівці та експерти Асоціації «Укрсадвинпром», фахівці провідних наукових установ - Інституту садівництва та Інституту аграрної економіки Національної академії аграрних наук Україні.

Формулювання цілей статті. Окремі актуальні проблеми розвитку садівництва в Україні, обгрунтування напрямів і джерел розбудови галузі, підвищення іiі конкурентоспроможності та участі у цьому процесі держави і ефективності задіяних важелів регулювання залишаються недостатньо вивченими. У статті було поставлено за мету розглянути та оцінити роль державної підтримки у відновленні та подальшому розвитку галузі садівництва України, проаналізувати недосконалості механізму державної допомоги галузі садівництва та визначити основні чинники підвищення іiі конкурентоспроможності.

Виклад основного матеріалу. Останнім часом в окремих секторах галузі садівництва спостерігається активність бізнесу у закладанні нових насаджень, упровадженні сучасних сортів та технологій вирощування, зберігання. переробки плодів та ягід, зумовлена зростаючим попитом на якісну плодово-ягідну продукцію на внутрішньому ринку та ціновою привабливістю і логістичною доступністю іiі експорту на ринки Європи та віддалені ринки. Проте за існуючого рівня розвитку галузь садівництва не можна визначити як конкурентоспроможну, незважаючи на те що Україна має низку переваг порівняно з іншими країнами для виробництва плодів, ягід, винограду.

Перш за все грунтово-кліматичні умови країни, які дають можливість успішно вирощувати всі плодові та ягідні культури помірного клімату, достатня кількість тепла і родючі грунти, які сприяють організації високоінтенсивного садівництва, формують високий виробничий потенціал для успішного його розвитку, садівнича галузь не в змозі задовольнити потреби населення в плодовій та ягідній продукції [1, с. 169].

Таблиця 1

Виробництво і споживання плодів, ягід в Україні на одну особу

\begin{tabular}{|c|c|c|}
\hline Роки & $\begin{array}{c}\text { Виробництво, плодів, ягід } \\
\text { на одну особу на рік, кг }\end{array}$ & $\begin{array}{c}\text { Споживання, плодів, ягід } \\
\text { на одну особу на рік, кг }\end{array}$ \\
\hline 1990 & 56 & 47 \\
\hline 1995 & 37 & 33 \\
\hline 1999 & 15 & 22 \\
\hline 2000 & 30 & 29 \\
\hline 2005 & 36 & 37 \\
\hline 2010 & 38 & 48 \\
\hline 2015 & 50 & 51 \\
\hline 2016 & 47 & 50 \\
\hline 2017 & 48 & 53 \\
\hline 2018 & 61 & 58 \\
\hline 2019 & 50 & 59 \\
\hline
\end{tabular}

Джерело: складено за [2, с. 17; 1, с. 170] 
Порівняння показників виробництва і споживання плодів та ягід населенням України вказує на те, що, незважаючи на те що обидва показники зростають, споживання переважає, а отже, виробляється плодово-ягідної продукції недостатньо. Неналежний рівень вітчизняного виробництва як за структурою, так і за регіонами. Виробництво плодів та ягід на особу в 2019 р. становило 50,4 кг, у тому числі зерняткових $-31,4$ кг, кісточкових $-12,8$, горіхів - 3,0, ягід - 3,2 кг. Такий рівень нижчий від норми споживання у 1,6 рази. При цьому потреби населення України по регіонах задовольняються нерівномірно [3, с. 18].

А порівняння рівня споживання садівничої продукції населенням розвинених країн з українцями свідчить про те, що цей рівень на третину менший. За розрахунками дослідників Інституту садівництва УААН, потреба в плодах і ягодах вітчизняного виробництва для раціонального забезпечення населення на 2020 р. має становити не менше 3,8 млн т, у тому числі обсяги експортних поставок - до 0,7 млн т та на переробку - не менше 0,2 млн т. Тобто існує необхідність додаткового формування загальної пропозиції вітчизняних плодів та ягід обсягом до 1,8 млн т [3, с. 17]. Реальна ж динаміка валових зборів плодів та ягід (окрім надурожайного 2018 р.) вказує на те (табл. 2), що забезпечити такий рівень у найближчі роки без надзвичайних дій вряд чи вдасться.

За роки трансформації української економіки галузь садівництва зазнала суттєвих змін. Площі під плодовими насадженнями скоротилися більше ніж утричі, при цьому у понад 2,5 рази зросла врожайність плодових та ягідних культур (рис. 1). У 2019 р. рівень виробництва плодів і ягід в Україні досяг 2 125,2 тис т, що більше за 2000 р. майже в 1,5 рази (табл. 2, рис. 1). Проте це ще на 37\% нижче, ніж було в 1990 р. Основні їхні обсяги одержують у господарствах населення, зокрема у 2019 р. $-83,5 \%$, або 1 774,5 тис т. Причому частка вирощених ними плодів становила 83,1\%, ягід $89,1 \%$. Серед плодів зерняткових культур у 2019 р. вироблялися переважно яблука $87,2 \%$ (1 153,4 тис т), із кісточкових - вишня - 31,0\% (167,5 тис т), із горіхів - грецькі горіхи - 100,0\% (126,1 тис т), із ягід - суниця - 45,8\% (62,6 тис т) [3, с. 17].

Тривалий занепад галузі садівництва, зумовлений як загальноекономічною нестабільністю, трансформаційним характером економіки, так і низкою специфічних причин, сформованих особливостями розвитку галузі садівництва, перетворив іії з високорентабельної галузі (83,8\% у 1990 р.) на низькорентабельну $(8,5 \%$ у 2007 р.) і навіть в окремі роки збиткову [1, с. 169].

Садівництво в Україні розвивалося не за фермерським типом, як це відбувалося у європейських країнах. У повоєнний період після глибокої руйнації було створено значна кількість радгоспів та спеціалізованих садівничих господарств, у яких за кошти держави було відновлено вже у 1950 р. 594 тис га садів. У подальші роки відбувалося значне розширення площ під садами та ягідниками. За 20 років (1950-1970) їхня площа збільшилася на 280\% і досягла 1,3 млн га, а врожайність - на 26\%. Урожайність плодових насаджень у колгоспах і радгоспах не перевищувала 25-30 ц/га, а в присадибних садах селян - у 1,5-2 рази вищою (40-50 ц/га) [5, с. 5]. Протягом 1971-1995 pp. відбувалося розкорчовування садів у неспеціалізованих господарствах, і площі плодових культур зменшилися до 0,7 млн га, як наслідок, урожайність плодових насаджень зросла і становила 40-60 ц/га, валові річні збори плодів - 1,4-3,5 млн т, здебільшого за рахунок інтенсифікації плодівництва у спеціалізованих і дослідних господарствах, а також розвитку колективного та присадибного садівництва [5, с. 5].

На тлі світових тенденцій у садівництві, коли запроваджувалися нові інтенсивні технології, нові сорти, українське садівництво залишалося на тому самому рівні й тих pecypcax, які дісталися господарствам із радянських часів. За таких умов галузь без значних інвестицій, заміни технологій, наявності належної інфраструктури розвиватися за рахунок власних джерел не змогла. 
Таблиця 2

Динаміка площ, валового збору, урожайності плодових та ягідних культур в Україні за категоріями господарств

\begin{tabular}{|c|c|c|c|c|c|}
\hline \multirow[b]{2}{*}{ Роки } & \multirow[b]{2}{*}{$\begin{array}{l}\text { Усі категорії } \\
\text { господарств }\end{array}$} & \multicolumn{4}{|c|}{ У тому числі: } \\
\hline & & $\begin{array}{c}\text { сільсько- } \\
\text { господарські } \\
\text { підприємства }\end{array}$ & $\begin{array}{c}\text { до усіх } \\
\text { категорій } \\
\text { господарств, \% }\end{array}$ & $\begin{array}{c}\text { господарства } \\
\text { населення }\end{array}$ & $\begin{array}{c}\text { до усіх } \\
\text { категорій } \\
\text { господарств, } \\
\text { \% }\end{array}$ \\
\hline 1990 & 679,8 & 336,4 & 49,5 & 343,4 & 50,5 \\
\hline 2000 & 378,0 & 243,5 & 64,4 & 134,5 & 35,6 \\
\hline 2005 & 265,5 & 124,8 & 47,0 & 140,6 & 53,0 \\
\hline 2010 & 223,2 & 75,1 & 33,6 & 148,1 & 66,4 \\
\hline 2115 & 206,0 & 58,2 & 28,3 & 147,8 & 71,7 \\
\hline 2016 & 196,7 & 51,0 & 25,9 & 145,7 & 74,1 \\
\hline 2017 & 198.5 & 51,2 & 25,8 & 147,3 & 74,2 \\
\hline 2018 & 198,5 & 50,7 & 25,5 & 147,8 & 74,5 \\
\hline 2019 & 194,0 & 46,2 & 23,8 & 147,8 & 76,2 \\
\hline \multicolumn{6}{|c|}{ Валовий збір, тис т } \\
\hline 1990 & 2901,7 & 1347,1 & 46,4 & 1554,6 & 53,6 \\
\hline 2000 & 1452,6 & 264,1 & 18,2 & 1188,5 & 81,8 \\
\hline 2005 & 1689,9 & 200,1 & 11,8 & 1489,8 & 88,2 \\
\hline 2010 & 1746,5 & 286,8 & 16,4 & 1459,7 & 83,6 \\
\hline 2115 & 2152,8 & 391,1 & 18,2 & 1733,2 & 80,5 \\
\hline 2016 & 2007,4 & 370,5 & 18,5 & 1636,8 & 81,5 \\
\hline 2017 & 2048,0 & 333,8 & 16,3 & 1714,3 & 83,7 \\
\hline 2018 & 2566,2 & 551,5 & 21,5 & 2014,7 & 78,5 \\
\hline 2019 & 2125,2 & 350,7 & 16,5 & 1774,5 & 83,5 \\
\hline \multicolumn{6}{|c|}{ Урожайність, т/га } \\
\hline 1990 & 4,2 & 3,9 & 93,0 & 4,5 & 104,7 \\
\hline 2000 & 3,8 & 1,1 & 28,9 & 8,8 & 231,6 \\
\hline 2005 & 6,4 & 1,6 & 25,1 & 10,6 & 166,2 \\
\hline 2010 & 7,8 & 3,8 & 48,8 & 9,9 & 126,0 \\
\hline 2115 & 10,5 & 7,1 & 67,8 & 11,8 & 112,7 \\
\hline 2016 & 10,2 & 7,3 & 71,1 & 11,2 & 110,1 \\
\hline 2017 & 10,3 & 6,5 & 62,9 & 11,6 & 112,9 \\
\hline 2018 & 12,9 & 10,8 & 83,7 & 13,6 & 105,7 \\
\hline 2019 & 10,9 & 7,5 & 68,6 & 12,0 & 110,0 \\
\hline
\end{tabular}

Джерело: складено за [4]

Протягом близько 20 років державна фінансова підтримка розвитку галузі садівництва реалізовувалася згідно 3 «Порядком справляння збору та використання коштів на розвиток виноградарства, садівництва і хмелярства», затвердженим Постановою Кабінету Міністрів України від 15.07.05 № 587 [6]. 


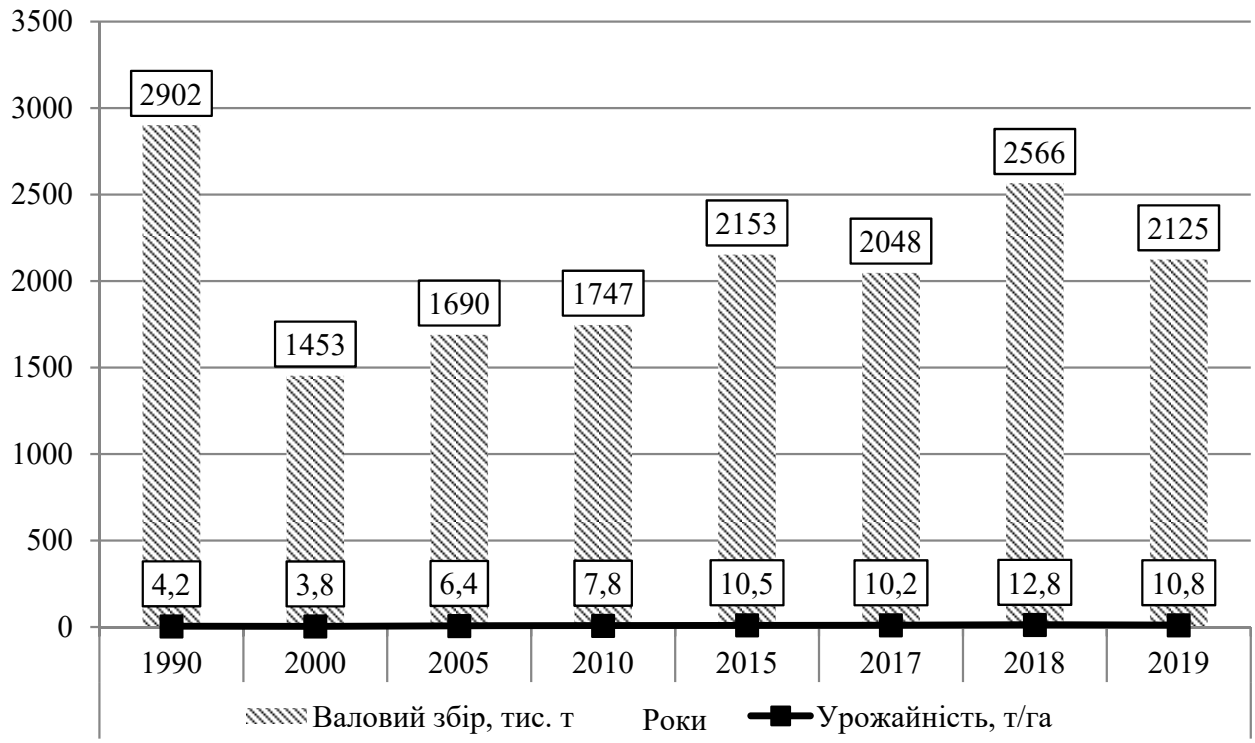

Рис. 1. Валовий збір, урожайність плодових та ягідних культур в Украӥні

Платниками збору є суб'єкти підприємницької діяльності незалежно від форм власності і підпорядкування, які реалізують в оптово-роздрібній торговельній мережі алкогольні напої та пиво. Ставка збору становила 1\% від виручки, одержуваної від реалізації цієї продукції. У подальшому ставка збору була змінена починаючи з 1 серпня 2011 р., платники збору сплачували його в розмірі 1,5\% від об'єкта оподаткування. Кошти, акумульовані із зазначеного збору на спеціальному рахунку, держава використовувала на відшкодування витрат, понесених суб'єктами господарювання на проведення робіт із закладення насаджень, догляду за ними до вступу у плодоношення (проєктні роботи, підготовка грунту і посадка, догляд за садами, встановлення шпалер і систем краплинного зрошення) та придбання матеріалів, необхідних для виконання таких робіт, а також саджанців, використаних для ремонту молодих насаджень, які постраждали від несприятливих погодних умов.

Згодом стало очевидним, що гальмівними чинниками відродження галузі садівництва стали відсутність сучасної інфраструктури зберігання та доробки товарної продукції садівництва, відсутність інвестицій у модернізацію галузі згідно із сучасними технологіями ведення садівництва. Упровадження таких заходів було ускладнене не лише через нестачу коштів, а й значну парцельованість товаровиробників у дрібному приватному секторі. Суттєвою перешкодою подальшого розвитку галузі стала нерозвиненість інфраструктури зберігання і сучасної переробки, об'єкти якої можуть бути ефективними лише завдяки ефекту масштабу.

У 2009 р. механізми державної фінансової підтримки було розширено, і до переліку таких, що підлягають компенсації, було включено витрати на будівництво холодильників із регульованим газовим середовищем ємкістю від 500 т для зберігання столових сортів винограду і плодів власного виробництва. Збільшення ставки збору до 1,5\% дало змогу підвищити рівень відшкодування цих витрат, а також забезпечити галузь коштами на модернізацію виробництва підприємств, які вирощують плоди й ягоди.

Проте скористатися такою допомогою змогли лише великі садівничі господарства, обсяги виробництва яких дають можливість ефективно використовувати сховища обсягом понад 500 т. Окрім того, навколо кожного сховища мають бути інші інфра- 
структурні споруди, будівництво яких потребує немалих власних коштів і недоступно садівникові-фермеру або одноосібному господарю.

Проте державна фінансова підтримка галузі на створення інфраструктури садівництва тривала, перелік напрямів підтримки було значно розширено. Так, у 2012 р. такими, що підлягають компенсації, були визначені витрати на:

- будівництво водонакопичувальних басейнів для забезпечення безперебійного водопостачання мереж краплинного зрошування 3 метою своєчасного поливу виноградників і плодових насаджень;

- розкорчовування непродуктивних багаторічних насаджень (після проведення посадки у звітному році нових садів і виноградників на аналогічній площі);

- придбання механізмів і техніки (у тому числі імпортного виробництва, яка не виробляється в Україні) для проведення технологічних операцій у виноградарстві, садівництві та хмелярстві і нового обладнання для сублімаційного висушування фруктів та ліній товарної обробки плодів;

- будівництво розсадницькими господарствами лабораторних комплексів для виробництва безвірусного садивного матеріалу;

- модернізацію холодильного та газового режимів зберігання у реконструйованих холодильниках ємністю від 500 т та будівництво камер швидкого заморожування плодів і ягід виробниками такої продукції [7].

Державна фінансова підтримка галузі садівництва в Україні здійснювалася тільки шляхом розподілу коштів зі спецфонду. Ефект від використання коштів спецфонду щороку зростав. На 1 грн витрачених у 2010 р. коштів отримано виручки від реалізації плодів 5,46 грн, що у 18 разів більше, ніж у 2000 р. У 2012 р. частка валових зборів плодів у сільськогосподарських підприємствах, сформована за рахунок державної підтримки, становила 90,5\% (327 тис т). До того ж урожайність закладених садів була вищою у 6,3 рази (7,9 т/га) проти існуючих насаджень, і це в умовах, коли не всі культури вступили у товарне плодоношення, зокрема кісточкові 2009-2012 рр. посадки та зерняткові 2010-2012 pp. [3, с. 21] Отже, показники зростання вказують на те, що державна фінансова підтримка галузі протягом 12 років створила передумови не лише для подолання занепаду, а й для початку іiі модернізації згідно з вимогами відкритої ринкової економіки.

У подальшому протягом 2013-2016 рр. після втрати чинності вказаного закону про підтримку галузі спеціальний фонд підтримки галузі припинив існування, коштів держава стала виділяти менше, що вплинуло на відновлення галузі.

У 2017 р. було прийнято рішення про подальшу підтримку галузі садівництва в рамках реалізації програми 2801350 «Державна підтримка розвитку хмелярства, закладення молодих садів, виноградників та ягідників і нагляд за ними». При цьому було змінено цільове призначення для використання бюджетних коштів, а саме бюджетні кошти надавалися суб'єктам господарювання галузі для часткової компенсації витрат за напрямами:

1) проведення робіт із закладення насаджень, догляду за ними до вступу у плодоношення;

2) придбання садивного матеріалу плодово-ягідних культур, винограду та хмелю;

3) будівництво холодильників із регульованим газовим середовищем для зберігання столових сортів винограду та плодів власного виробництва, а також придбання ліній товарної обробки плодів;

4) будівництво розсадницькими господарствами лабораторних комплексів для виробництва безвірусного садивного матеріалу;

5) придбання механізмів та техніки для проведення технологічних операцій у виноградарстві, садівництві та хмелярстві і нового обладнання для сублімаційного висушування фруктів [7]. 
У 2019 р. фінансування за цією програмою було зосереджене лише на двох напрямах:

- придбання садивного матеріалу плодово-ягідних культур, винограду та хмелю;

- будівництво холодильників із регульованим газовим середовищем та об'єктів із заморожування плодово-ягідної продукції, придбання ліній товарної обробки плодів, обладнання для сублімаційного висушування фруктів.

На ці цілі було передбачено виділення коштів із державного бюджету на загальну суму 400 млн грн.

У 2020 р. обсяги державної підтримки залишалися на тому самому рівні, проте також більше уваги було приділено закладанню насаджень та створенню інфраструктури для зберігання та доробки:

- саджанці, шпалера, краплинне зрошення;

- нове будівництво та реконструкція холодильників, цехів первинної переробки, об'єктів із заморожування;

- придбання ліній товарної обробки плодів та ягід, автоматизованих ліній із висушування плодів, ягід та хмелю, ліній із переробки власно вирощених плодів, ягід та технічних сортів винограду, техніки та обладнання для проведення технологічних операцій.

Відшкодування вартості закладання насаджень відбувалося на рівні 80\% вартості, решта - на рівні $30 \%$ [8].

У результаті державної підтримки галузі садівничим господарствам вдалося значно збільшити площі насаджень молодих садів та ягідників. Протягом 2017-2019 рр. закладено 13,6 тис га плодових та ягідних насаджень. Окрім того, у результаті вступу в товарне плодоношення молодих садів спостерігається збільшення обсягів виробництва плодів та ягід у сільськогосподарських підприємствах за останні десять років на 22,3\% (у 2019 р. - 350,7 тис т). Проте, як зазначає експерт із садівництва I.А. Сало, відтворення багаторічних насаджень поки залишається недостатнім, оскільки площі вибуття старих насаджень практично в два рази більші [3, с. 21-22].

Проте подальша державна фінансова підтримка галузі сприятиме укріпленню iï потенціалу, підвищенню економічної ефективності використання усіх ресурсів галузі та, відповідно, іiі конкурентоспроможності. Так, уже в 2020 р. виділені державою кошти на підтримку галузі частково були спрямовані на будівництво об'єктів переробки і зберігання. Зокрема, згідно 3 паспортом бюджетної програми на 2020 р. Міністерства розвитку економіки, торгівлі та сільського господарства України за КПКВК 1201150 «Фінансова підтримка сільгоспвиробників», затвердженим Наказом Мінекономіки України від 15.05.2020 № 896, фінансування спрямоване на закладання нових насаджень збільшить наявні площі на 2,1\% (2 000 га), потужності холодильників та камер з обмеженим газовим середовищем для зберігання плодів на 4,5\% (18,0 тис т), збільшить потужності переробки на 3,0\% (сім цехів побудовано), сприятиме розвитку зрошення у садівництві тощо [9].

Незважаючи на певні обмеження стосовно окремих господарств (суб' єкт господарювання не може отримати в один рік більше 25 млн грн), державне фінансування розподіляється нерівномірно як за регіонами, так і за окремими суб'єктами господарювання.

Так, згідно з державною фінансовою підтримкою, у 2018 р. більше коштів отримали господарства восьми областей України: Вінницької, Дніпропетровської, Житомирської, Закарпатської, Київської, Львівської, Хмельницької, Чернівецької 295, млн грн, або практично три четвертих від виділеного обсягу фінансування. Підприємства, які фінансувалися за обома напрямами (п'ять господарств), отримали більше ніж по 16 млн грн державного фінансування. Окрім того, серед отримувачів державної підтримки представлені основні експортери плодової та ягідної продукції, наприклад ТОВ «Фамелі гарден», ФГ «Гадз», ТОВ «Блу Беррі» та ін. 
Терміни надання коштів державної підтримки не сприяють раціональному плануванню бізнесу. Так, згідно зі Звітом про використання у 2018 р. бюджетних коштів у розрізі напрямів їх використання та суб'єктів господарювання за програмою 2801350 «Державна підтримка розвитку хмелярства, закладення молодих садів, виноградників та ягідників і нагляд за ними» рішення про надання коштів по більшій частині компенсацій (160 млн грн) було прийнято наказом відповідного міністерства лише 20 грудня [8]. Незважаючи на позитивні кроки профільного міністерства з удосконалення механізму та адміністрування державної підтримки розвитку садівництва, приводів для поліпшення ситуації ще вистачає.

Відновлення в окремих секторах галузі садівництва, на нашу думку, можливе на основі співпраці різних учасників за моделлю державно-приватного партнерства. Такий досвід є в країнах Європи. Так, розведення малини в Інституті Джеймса Хаттона, що у м. Данді (Шотландія), фінансується шотландським урядом, групою розплідників, а також переробними підприємствами, що разом утворюють консорціум під назвою Raspberry Breeding Consortium (RBC) [10, c. 29].

Цільова державна фінансова підтримка підприємств садівництва для відновлення садів, будівництва сучасних фруктосховищ та інших об'єктів інфраструктури галузі спряла підвищенню конкурентоспроможності галузі, що дало можливість окремим товаровиробникам пропонувати свою продукцію на світовому ринку. Так, за даними Держстату, у 2019 р. в Україні вироблено понад 2,1 млн т плодово-ягідної продукції. Утім, експортовано лише 107 тис т, тобто трішки більше 5\%, до того ж із них 50\% припало на яблука, 38\% - на волоський горіх, показники з решти культур мізерні [11, с. 7]. Суттєвими перешкодами виходу вітчизняних виробників ягід та фруктів на світовий ринок є низка чинників, серед них:

- відсутність достатніх обсягів продукції преміум-класу для пропозиції на європейському й інших ємних та вибагливих ринках;

- значний рівень конкуренції на європейському ринку та відсутність напрацьованих партнерів-покупців з інших регіонів світу;

- неосвоєні ринки інших країн;

- немає належної результативної взаємодії державних інституцій та товаровиробників у частині освоєння норм і правил світової торгівлі (фітосанітарний контроль, сертифікація, дослідження ринків, інформаційна підтримка тощо).

Інша група проблем розвитку галузі садівництва, що потребує, на нашу думку, державного регулювання, - це економічні умови, в яких сьогодні розвивається бізнес у садівництві. Як відомо, садівництво - це галузь, яка потребує довгих інвестиційних ресурсів, перш за все через те, що молодий закладений сад за щорічних витрат на догляд починає приносити доход через 5-8 років. Немає підтримки з боку держави й у сфері агрострахування.

Галузь садівництва розвивається в умовах, коли виробники різних форм господарювання, реалізатори та багаточисельні посередники і торгівельні мережі знаходяться в різних податкових умовах, що не сприяє розвитку конкурентного середовища, формує неефективні та несправедливі співвідношення у розподілі доходів між учасниками ринку продукції садівництва, перш за все не на користь виробників. Серед виробників $\epsilon$ платники податку на прибуток та ПДВ і ті, що їх не платять, що призводить до суттєвого зростання цін на продукцію садівництва на внутрішньому ринку, скорочення попиту та зменшення іiї споживання населенням.

Значний сектор малих товаровиробників плодів та ягід, що вирощують товарну продукцію на невеликих земельних ділянках та в особистих селянських господарствах населення, потребує більш уважного дослідження, оцінки та цивілізованого ставлення до розбудови садівничої галузі.

Підтримка з боку держави та громадських інституцій кооперації особистих селянських господарств, формування ними партнерських відносин із великим бізнесом 
переробки та торгівлі виступають необхідними умовами організаційної допомоги сільському населенню отримувати доходи на легальній основі, використовуючи власний ресурсний та людський потенціал, та сприяти розвитку сільських територій [12, с. 78].

Однак лише заходи з державної підтримки національного сільського господарства не вирішують проблеми економічної доступності продовольства для всіх верств населення країни. Макроекономічна стабілізація і збалансованість - це єдиний шлях зміцнення і гарантування продовольчої безпеки. Механізм взаємозалежності при цьому такий: макроекономічний розвиток економіки зумовлює зростання реальних доходів населення і, відповідно, попиту на продовольство, який, своєю чергою, визначає темпи та якість зростання в агропродовольчому секторі [13, с. 30].

Отже, заходи державної підтримки галузі садівництва для її відновлення на тлі загального зростання економіки та доходів населення сприятимуть подальшому розвитку галузі.

Висновки. Особливості галузі садівництва як капіталоємної, трудоємної, особливо чутливої до кліматичних змін та погодних ризиків зумовили глибокий ії занепад у період економічних реформ у сільському господарстві України, який було підсилено приватизаційними процесами, падінням доходів населення і скороченням попиту на плодово-ягідну продукцію, відсутністю адекватної інфраструктури зберігання, переробки плодів та ін. Скорочення площ насаджень спостерігалося у півтора рази, а валових зборів плодів та ягід - більше ніж у два рази. Відродженню галузі та формуванню іiї конкурентоспроможності сприяла державна фінансова підтримка протягом близько 20 років. Ефективним напрямом розвитку галузі стала реалізація державної програми підтримки галузі через механізм накопичення коштів зі спеціального збору та надання аграрним підприємствам допомоги у вигляді компенсації витрат на закладання нових садів, будівництво холодильників та об'єктів переробки, спорудження шпалер, краплинного зрошення тощо. Протягом упровадження заходів державної підтримки вдалося призупинити кризовий сценарій функціонування галузі та забезпечити іiі переважно інноваційний, ринково орієнтований розвиток, коли за скорочення площ насаджень урожайність зросла більше ніж у два рази, зростає експортний складник виробництва, формується сучасна інфраструктура. Однак для досягнення належного рівня забезпечення населення країни плодово-ягідною продукцією та нарощування експортного потенціалу галузі необхідна подальша фінансова підтримка цього сектору з пріоритетною увагою на вдосконалення механізмів державної підтримки, цільове спрямування коштів на об'єкти зберігання і переробки, підтримку кооперативного руху, особливо у ягідництві. Перспективною, на нашу думку, може бути реалізація різноманітних локальних проєктів за участю держави та органів місцевого самоврядування, спрямованих на розвиток малого бізнесу у плодово-ягідному виробництві у поєднанні з крафтовим виробництвом продукції їх переробки, рекреаційними послугами, цільовим сільським туризмом і тематичним відпочинком у регіонах з туристичними принадами, високим рівнем безробіття.

\section{Список використаних джерел:}

1. Аграрний сектор економіки України (стан та перспективи розвиту) / М.В. Присяжнюк та ін. ; за ред. М.В. Присяжнюка та ін. Київ : ННЦ «ІАЕ», 2011. 1008 с.

2. Кернасюк Ю.В. Галузь садівництва: розвиток, тенденції та перспективи Агробізнес сьогодні. 2020. № 17. С. 14-19.

3. Сало І.А. Розвиток ринку плодів та ягід в Україні. Економіка АПК. 2020. № 3. С. 16-23.

4. Статистична інформація Державної служби статистики України. URL: http://www.ukrstat.gov.ua/ (дата звернення: 12.01.2021).

5. Куян В.Г. Плодівництво. Київ : Аграрна наука. 1998. 472 с.

6. Про затвердження Порядку використання коштів, передбачених у державному бюджеті для розвитку виноградарства, садівництва і хмелярства : Постанова Кабінету Міністрів України 
від 15.07.2005 № 587 (зі змінами). URL: https://zakon.rada.gov.ua/laws/show/587-2005-\%D0\%BF (дата звернення: 02.03.2021).

7. Про розподіл коштів за бюджетною програмою 2801350 «Державна підтримка розвитку хмелярства, закладення молодих садів, виноградників та ягідників і нагляд за ними» : Наказ М-ва аграрної політики та продовольства України від 13.08.2019 № 469-19. URL: http://search.ligazakon.ua/1_doc2.nsf/link1/FN054904.html (дата звернення: 27.02.2021).

8. Про внесення змін до Порядку використання коштів, передбачених у державному бюджеті для розвитку виноградарства, садівництва і хмелярства : Постанова КМ України № 279 від 18 березня 2020 p. URL: https://zakon.rada.gov.ua/laws/show/279-2020-\%D0\%BF\#Text.

9. Про затвердження паспорта бюджетної програми на 2020 р. : Наказ М-ва розвитку, економіки, торгівлі та сільського господарства України від 15.05.2020 № 896. URL: https://apk.cg.gov.ua/web_docs/2141/2020/05/docs/\%D0\%9F\%D0\%B0\%D1\%81\%D0\%BF\%D0\%B E\%D $1 \% 80 \% \mathrm{D} 1 \% 82 \% 20 \% \mathrm{D} 0 \% \mathrm{BF} \% \mathrm{D} 1 \% 80 \% \mathrm{D} 0 \% \mathrm{BE} \% \mathrm{D} 0 \% \mathrm{~B} 3 \% \mathrm{D} 1 \% 80 \% \mathrm{D} 0 \% \mathrm{~B} 0 \% \mathrm{D} 0 \% \mathrm{BC} \% 20$ $\% \mathrm{D} 0 \% \mathrm{~B} 2 \% \mathrm{D} 1 \% 96 \% \mathrm{D} 0 \% \mathrm{~B} 4 \% 2015.05 .2020$.pdf (дата звернення: 24.03.2021).

10. Вернер Т. Новинки селекції від шотландського інституту. Ягідник. 2019. № 1. С. 29-31.

11. Фруктово-горіхова дієта... як змінюється вирощування і споживання культур цих сегментів агровиробництва в Україні. Садівнищтво і виноградарство. Технології та інновачіï. 2020. № 4. C. 7.

12. Галат Л. Кооперативи та гібридні форми економічної співпраці малих товаровиробників у плодоовочевій галузі України. Агросвіт. 2020. № 9. С. 70-78.

13. Забезпечення конкурентоспроможності аграрного сектору економіки України на внутрішньому і зовнішньому ринках : наукова доповідь / за ред. акад. УААН, чл.-кор. УААН Б.Й. Пасхавера. Київ : Ін-т екон. та прогнозув., 2007. 260 с.

\section{References:}

1. Prysyazhnyuk M.V., Zubets' M.V., Sabluk P.T., at al (2011) Ahrarnyy sektor ekonomiky Ukrayiny (stan ta perspektyvy rozvytu) [Agrarian sector of the economy of Ukraine (state and prospects of development)]. for ed . M.V. Prysyazhnyuka, M.B. Zubetsya, P.T. Sabluka, V.YA. Messel'-Veselyaka, M.M. Fedorova. Kyiv: NNTs «IAE» (in Ukrainian).

2. Kernasyuk Y.V. (2020) Haluz' sadivnytstva: rozvytok, tendentsiyi ta perspektyvy [Horticulture: development, trends and prospects]. Ahrobiznes sohodni, no. 17, pp. $14-19$.

3. Salo I.A. (2020) Rozvytok rynku plodiv ta yahid v Ukrayini [Development of the fruit and berries market in Ukraine]. Ekonomika APK, no. 3, pp. 16-23.

4. Statystychna informatsiya Derzhavnoyi sluzhby statystyky Ukrayiny [Statistical information of the State Statistics Service of Ukraine]. Available at: http://www.ukrstat.gov.ua (accessed 12 January 2021).

5. Kuyan V.H. (1998) Plodivnytstvo [Fruit growing.]. Kyiv: Ahrarna nauka. (In Ukrainian)

6. Pro zatverdzhennia Poriadku vykorystannia koshtiv, peredbachenykh u derzhavnomu biudzheti dlia rozvytku vynohradarstva, sadivnytstva i khmeliarstva: Postanova Kabinetu Ministriv Ukrainy vid 15.07.2005 r. № 587 [On approval of the Procedure for using funds envisaged in the state budget for development of viticulture, horticulture and humiculture: Resolution of the Cabinet of Ministers of Ukraine from 15.07.2005, No. 587]. (2005). Available at: https://zakon.rada.gov.ua/ laws/ show/587-2005-\%D0\%BF [In Ukrainian]. (accessed 02 March 2021).

7. Pro rozpodil koshtiv za biudzhetnoiu prohramoiu 2801350 "Derzhavna pidtrymka rozvytku khmeliarstva, zakladannia molodykh sadiv, vynohradnykiv ta yahidnykiv I nahliad za nymy": zatv. nakazom M-va ahrarnoi polityky ta prodovolstva Ukrainy vid 13.08.2019 r. № 469-19 [On the allocation of funds under the budget program 2801350 "State support for the development of hop growing, laying young gardens, vineyards and berries and their supervision": Order of the Ministry of Agrarian Policy and Food of Ukraine from 13.08.2019, No. 469-19]. (2019). Available at: http://search.ligazakon.ua/ 1_doc2.nsf/link1/FN054904.html [in Ukrainian] (accessed 27 February 2021).

8. Pro vnesennya zmin do Poryadku vykorystannya koshtiv, peredbachenykh u derzhavnomu byudzheti dlya rozvytku vynohradarstva, sadivnytstva i khmelyarstva:Postanova KM Ukrayiny № 279 vid 18.03.2020 r. [On amendments to the Procedure for the use of funds provided in the state budget for the development of viticulture, horticulture and hop-growing: Resolution of the Cabinet of Ministers of Ukraine No. 279 of March 18, 2020]. Available at: https://zakon.rada.gov.ua/laws/ show/279-2020-\%D0\%BF\#Text [in Ukrainian] (accessed 27 February 2021). 
9. Pro zatverdzhennya pasporta byudzhetnoyi prohramy na $2020 \mathrm{r}$.: zatv. nakazom M-va rozvytku, ekonomiky, torhivli ta sil's'koho hospodarstva Ukrayiny vid 15.05.2020 r. № 896 [On approval of the passport of the budget program for 2020: approved. by the order of the Ministry of Development, Economy, Trade and Agriculture of Ukraine dated 15.05.2020 № 896]. Available at: https://apk.cg.gov.ua/web docs $/ 2141 / 2020 / 05 /$ docs $/ \% \mathrm{D} 0 \% 9 \mathrm{~F} \% \mathrm{D} 0 \% \mathrm{~B} 0 \% \mathrm{D} 1 \% 81 \% \mathrm{D} 0 \% \mathrm{BF} \% \mathrm{D} 0 \% \mathrm{BE} \% \mathrm{D} 1 \% 80 \% \mathrm{D} 1 \% 82 \% 20$ $\% \mathrm{D} 0 \% \mathrm{BF} \% \mathrm{D} 1 \% 80 \% \mathrm{D} 0 \% \mathrm{BE} \% \mathrm{D} 0 \% \mathrm{~B} 3 \% \mathrm{D} 1 \% 80 \% \mathrm{D} 0 \% \mathrm{~B} 0 \% \mathrm{D} 0 \% \mathrm{BC} \% 20 \% \mathrm{D} 0 \% \mathrm{~B} 2 \% \mathrm{D} 1 \% 96 \% \mathrm{D} 0$ $\%$ B4\%2015.05.2020.pdf (accessed 24 March 2021).

10. Verner T. (2019) Novynky selektsiyi vid shotlands'koho instytutu [Novelties of selection from the Scottish Berry Institute]. Yahidnyk, no. 1, pp. 29-31.

11. Fruktovo-horikhova diyeta...yak zminyuyet'sya vyroshchuvannya i spozhyvannya kul'tur tsykh sehmentiv ahrovyrobnytstva v Ukrayini (2020) [Fruit and nut diet... how the cultivation and consumption of crops in these segments of agricultural production in Ukraine is changing]. «Sadivnytstvo $i$ Vynohradarstvo. Tekhnolohiyi ta innovatsiyi», no. 4, pp. 7.

12. Galat L. (2020) Kooperatyvy ta hibrydni formy ekonomichnoyi spivpratsi malykh tovarovyrobnykiv u plodoovocheviy haluzi Ukrayiny [Cooperatives and hybrid forms of economic cooperation of small producers in the fruit and vegetable industry of Ukraine]. Agrosvit, no. 9, pp. 70-78.

13. Paschaver B.J. at al (2007) Zabezpechennya konkurentospromozhnosti ahrarnoho sektora ekonomiky Ukrayiny na vnutrishn'omu i zovnishn'omu rynkakh: Naukova dopovid' [Ensuring the competitiveness of the agricultural sector of Ukraine's economy in domestic and foreign markets: Scientific report]. B.Y. Paskhaver (Ed). Kyiv: Instytut ekon. ta prohnozuv. (in Ukrainian) 